\title{
OUTCOMES OF COVID-19 IN EGYPTIAN PATIENTS
}

\author{
By \\ Ahmed M Khamiss ${ }^{1}$, Magdy El-Dahshan ${ }^{1}$, Fathy El-Ghamery ${ }^{1}$, \\ Mohamed Aggag ${ }^{2}$, Alaa Hashim ${ }^{3}$ and Ahmed Eliwa ${ }^{1}$ \\ ${ }^{1}$ Department of Internal Medicine, Faculty of Medicine, Al-Azhar University, Cairo, Egypt \\ ${ }^{2}$ Department of Diagnostic Radiology, Faculty of Medicine, Al-Azhar University, Cairo, \\ Egypt \\ ${ }^{3}$ Department of Hepatology, Gastroenterology and Infectious Diseases, Faculty of \\ Medicine, Al-Azhar University, Damietta Egypt
}

Corresponding author: Ahmed M Khamiss

Mobile: 01007828428, E-mail: drahmedkhamiss2017@gmail.com

\begin{abstract}
Background: Coronavirus disease 2019 (COVID-19), caused by severe acute respiratory syndromecoronavirus-2 (SARS-CoV2), is an ongoing pandemic that has already affected millions of patients worldwide, and is associated with significant morbidity and mortality burden.

Objective: To characterize the clinical manifestations and outcomes of COVID-19 in Egyptian patients.

Patients and Methods: This was a retrospective cohort study conducted on 333 subjects with COVID-19 who were admitted to Al-Azhar University Specialized Hospital, Quarantine Hospital, and some patients during follow up after discharge from other quarantine hospitals, during the period from 15th of April, 2020 to 31 st of August, 2020. Presenting clinical manifestations, laboratory findings, imaging findings and mortality rate were recorded from electronic medical records and sometimes from patients.

Results: The vast majority had cough (82.6\%) and fever (51.7\%), while $23.4 \%$ had dyspnea among COVID19 patients. There was a significant older age among died cases $(66.4 \pm 17.4$ years old) than recovered cases $(40.3 \pm 14.9$ years old $)(p-$ value $<0.001)$. The overall co-morbiditis $89.5 \%$ and $38.5 \%$ in died and recovered cases respectively. Significant differences (p-value $<0.001$ ) were found between died and recovered patients regarding, Lymphocytes and neutrophilic/ lymphocytic ratio (NLR). The C-reactive protein (CRP), ferritin and D-Dimer were higher in died cases. Crazy paving appearance was the findings in CT chest in deceased patients. The mortality rate was $5.7 \%$.
\end{abstract}

Conclusions: Age, obesity, lymphopenia, D. dimer, CT chest findings and other co-morbid disease could be considered as a predictor of outcome among COVID-19 patients.

Keywords: COVID-19, Egypt, clinical characterizations, hematological indices, inflammatory markers, mortality.

\section{INTRODUCTION}

In December 2019, a cluster of patients with pneumonia of undetermined etiology was recognized in Wuhan, Hubei, China (Huang et al., 2020). Subsequently, a novel coronavirus (SARS-CoV-2) was identified from lower respiratory tract samples obtained from affected patients (Zhu et al., 2020). Structural analysis suggests that SARS-CoV-2 might be able 
to bind to the angiotensin-converting enzyme (ACE) 2 receptor, as SARS-CoV in humans (Lu et al., 2020). Defining the clinical characteristics and associated outcomes of patients diagnosed with coronavirus disease (COVID-19) is integral to improving our understanding and management of this disease. Several articles have recently been published, describing the clinical features and outcomes of retrospective cohorts of patients with COVID-19 (Guan et al., 2020, Richardson et al., 2020 and Zhou et al., 2020). The full clinical presentation of COVID-19 still not understood, but among the most common presentations were dry cough, fever, dyspnea, and pneumonia. To date, no effective vaccines or specific drugs have been reported that specifically act against COVID-19 (Xu et al., 2020). People with co-morbidities are at risk for COVID-19 pneumonia Furthermore, blood biomarkers differ significantly among COVID- 19 patients with different disease severities (Guan et al., 2020). Importantly, significant differences have been noted in the clinical and demographic features of COVID-19 patients in different regions of the world (Lippi et al., 2020). As the novel coronavirus continues to evolve, there are still many limitations to our knowledge of who exactly this virus would impact critically.

The present work aimed to study the clinical features and characteristics of patients hospitalized with SARS- CoV2 infection at our community, specifically to analyses the factors associated with disease severity and mortality.

\section{PATIENTS AND METHODS}

This retrospective cohort study has been conducted on 333 COVID-19 patients who were admitted to Al-Azhar University specialized hospital, quarantine hospital and some patients during follow up after discharge from other quarantine hospitals, during the period from 15th of April 2020 to 31 of August 2020. Before starting the study, approval from the Ethics Committee, Faculty of Medicine, Al-Azhar University, Cairo, Egypt, was obtained. Additionally, an informed consent was obtained from all subjects before recruitment for use of their medical reports. Diagnosis of COVID-19 is based on the history of epidemiologic exposure, clinical manifestations; radiological and laboratory findings of COVID-19 infection (Wang et al., 2020). The inclusion criteria included, positive result confirmed by standard SARS-CoV-2 RTPCRTest, age $\geq 18$ years with self-care ability and respiratory rate more than 25 per/ minute with blood oxygen saturation less than or equal to $95 \%$, at rest. There were exclusion criteria that include respiratory rate less than 25 or blood oxygen saturation more than $95 \%$, at rest, other active infectious disease and mental illness. All patients were subjected to detailed medical history for age, BMI, smoking, co-morbidities and clinical characterizations (cough, dyspnea, fever, sore throat, and diarrhea). Laboratory investigations were done at diagnosis including complete blood count, neutrophilic count, lymphocytic count and neutrophilic/ lymphocytic ratio. Liver function tests (SGPT, SGOT, serum bilirubin and serum albumin), renal function tests (serum creatinine and blood 
urea), fasting blood sugar and HbA1c for diabetic patients, CRP, Ferritin, D. Dimer. Radiological investigations in the form of X-ray Chest and CT Chest were reported by radiologist for all patients. On CT chest, each of the Five lung lobes was visually scored from 0 to 5 as follows: 0 , no involvement; $1,<5 \%$ involvement; 2 , $25 \%$ involvement; $3, \quad 26 \%-49 \%$ involvement; 4, 50\%-75\% involvement; and 5,> 75\% involvement (Pan et al., 2020). All patients were received medical treatment according to protocols of ministry of health and population-Egypt. Confirmed COVID-19 cases were categorized into recovered and died cases.

\section{Statistical analysis:}

Data were analyzed using Statistical Program for the Social Sciences (SPSS) version 24. Quantitative data were expressed as mean \pm standard deviation (SD) and median qualitative data were expressed as frequency and percentage.

Mann-Whitney U test was used when comparing between two means (for abnormal distributed data). Chi-square test was used when comparing between nonparametric data. P-value $<0.05$ was considered significant.

\section{RESULTS}

The mean \pm SD age of was $41.8 \pm 16.2$ years, there were $52.3 \%$ males and $47.7 \%$ females, BMI ranged from $20-42 \mathrm{~kg} / \mathrm{m} 2$, there were $28.5 \%$ smokers and $71.5 \%$ non-smokers. The patients were categorized according to outcome into died cases (19 patients) and recovered cases (314 patients). There was a significant older age among died cases mean \pm SD $(66.4 \pm 17.4$ years old $)$ than recovered cases mean $\pm \mathrm{SD}(40.3 \pm 14.9$ years old) (p-value < 0.001). The BMI was higher in died cases $(29.4 \pm 5.1$ $\left.\mathrm{kg} / \mathrm{m}^{2}\right)$ than recovered cases $(24.7 \pm 3.07$ $\mathrm{kg} / \mathrm{m}^{2}$ ). However, there is no significant difference ( $\mathrm{p}$-value > 0.05) were found between died and recovered patients as regard sex and smoking (Table 1). 
Table (1): Description of demographic data in all studied patients and comparisons between died and recovered cases among COVID-19 patients

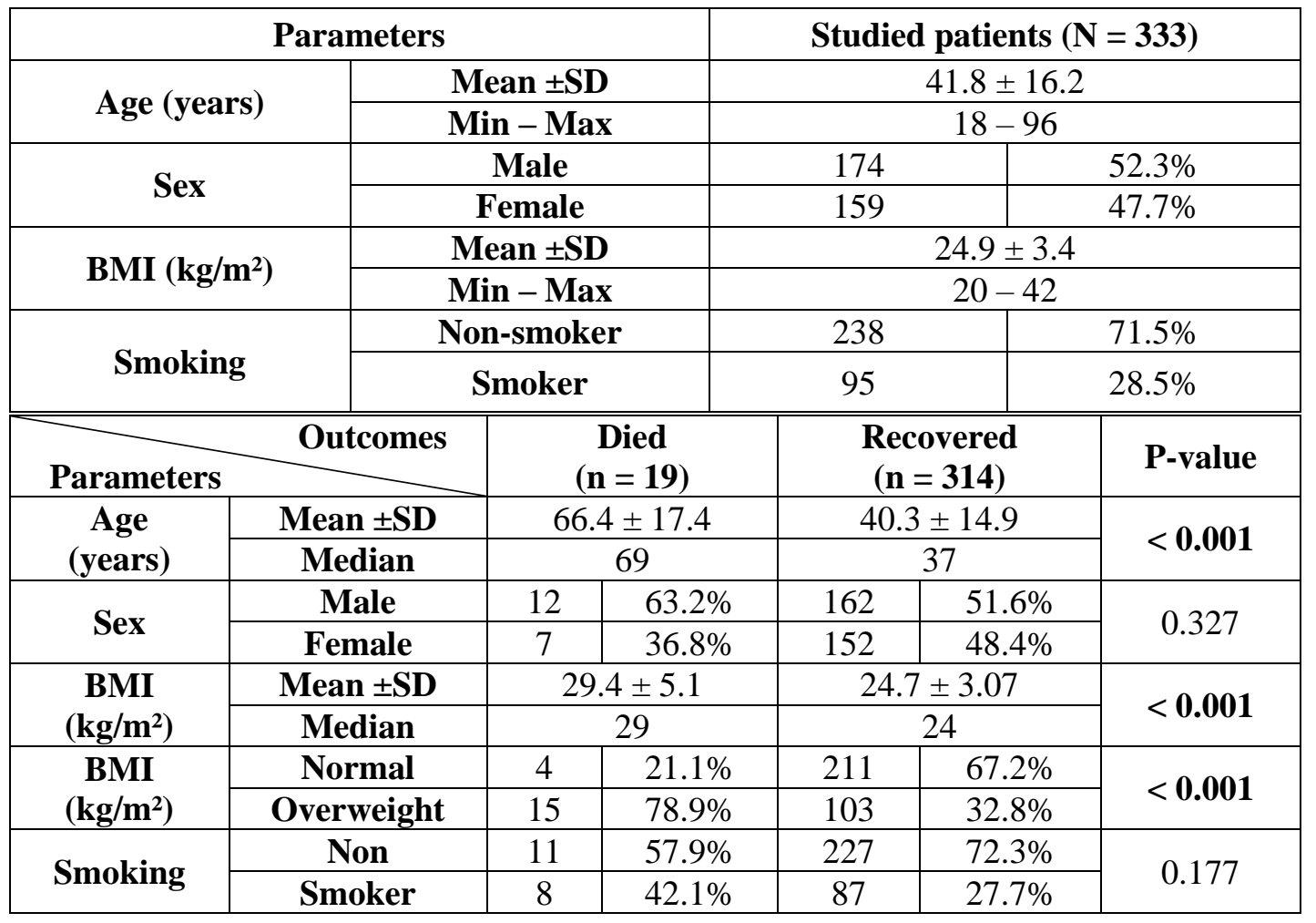

The vast majority had cough $(82.6 \%)$ and fever $(51.7 \%)$, the sore throat was reported in $42.9 \%$ while $23.4 \%$ had dyspnea as initial clinical presentation and only $0.9 \%$ had diarrhea as initial presentations, but all patients after that had dyspnea (Figure 1).

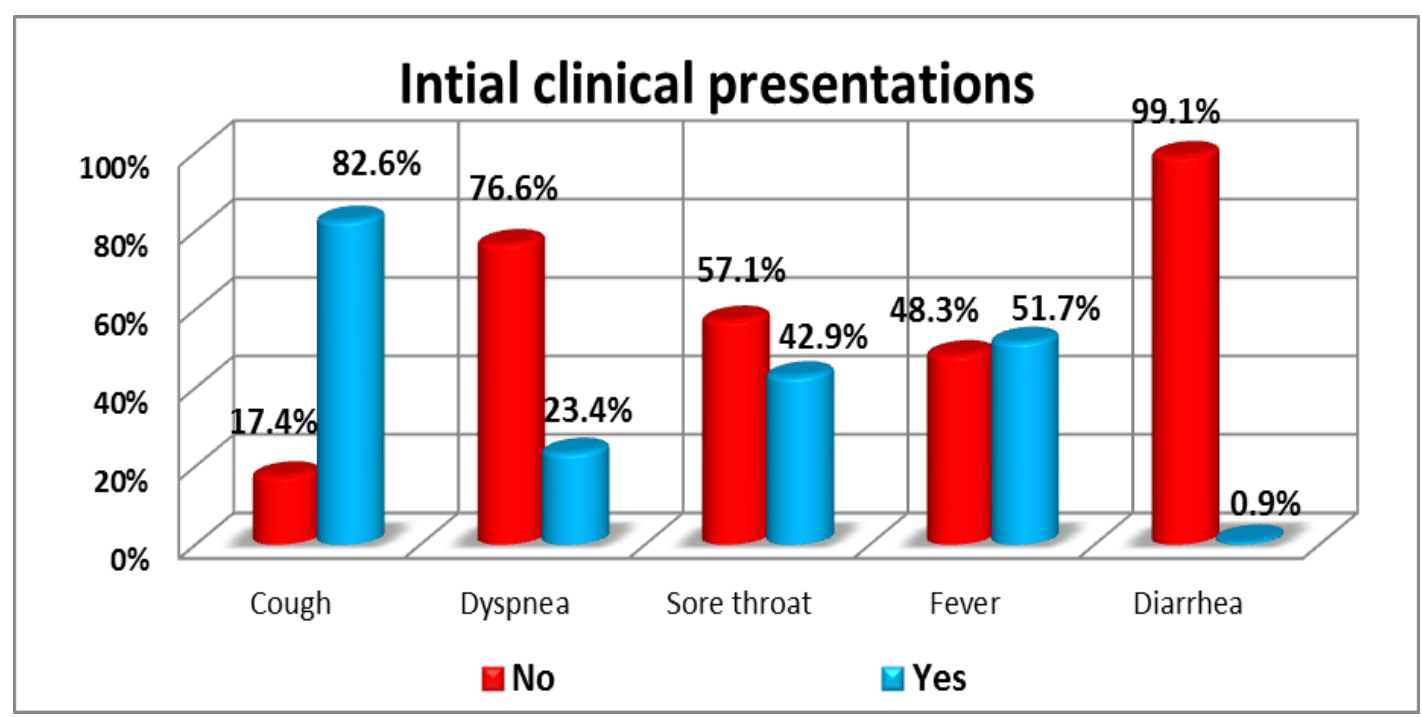

Figure (1): Clinical characteristics on initial hospital presentations 
Significant difference (p-value < 0.001 ) were found between died and recovered patients as regard chronic diseases (DM, HTN, IHD, CKD \& comorbidity) as the percentage of diabetes, hypertension. Ischemic heart disease, chronic kidney disease and COPD were higher in died patients. The overall comorbidities $89.5 \%$ and $38.5 \%$ in died and recovered cases respectively (Table 2).

Table (2): Comparisons of chronic diseases between died and recovered cases among COVID-19 patients.

\begin{tabular}{|c|c|c|c|c|c|c|}
\hline \multicolumn{2}{|c|}{$\begin{array}{ll}\text { Parameters } & \text { Outcomes } \\
\end{array}$} & \multicolumn{2}{|c|}{$\begin{array}{c}\text { Died } \\
(n=19)\end{array}$} & \multicolumn{2}{|c|}{$\begin{array}{c}\text { Recovered } \\
(n=314)\end{array}$} & \multirow{3}{*}{$\frac{p \text {-value }}{<0.001}$} \\
\hline \multirow{2}{*}{$\begin{array}{l}\text { Diabetes } \\
\text { Mellitus }\end{array}$} & No & 3 & $15.8 \%$ & 257 & $81.8 \%$ & \\
\hline & Yes & 16 & $84.2 \%$ & 57 & $18.2 \%$ & \\
\hline \multirow{2}{*}{ Hypertention } & No & 5 & $26.3 \%$ & 239 & $76.1 \%$ & \multirow{2}{*}{$<0.001$} \\
\hline & Yes & 14 & $73.7 \%$ & 75 & $23.9 \%$ & \\
\hline \multirow{2}{*}{$\begin{array}{l}\text { Ischemic Heart } \\
\text { Disease }\end{array}$} & No & 14 & $73.7 \%$ & 311 & $99.0 \%$ & \multirow{2}{*}{$<0.001$} \\
\hline & Yes & 5 & $26.3 \%$ & 3 & $1.0 \%$ & \\
\hline \multirow{2}{*}{$\begin{array}{c}\text { Chronic } \\
\text { Kidney Disease }\end{array}$} & No & 15 & $78.9 \%$ & 311 & $99.0 \%$ & \multirow{2}{*}{$<0.001$} \\
\hline & Yes & 4 & $21.1 \%$ & 3 & $1.0 \%$ & \\
\hline \multirow{2}{*}{$\begin{array}{c}\text { Chronic } \\
\text { Obstructive } \\
\text { Pulmonary } \\
\text { Disease }\end{array}$} & No & 12 & $63.2 \%$ & 257 & $81.8 \%$ & \multirow[b]{2}{*}{$0.045 \mathrm{~S}$} \\
\hline & Yes & 7 & $36.8 \%$ & 57 & $18.2 \%$ & \\
\hline \multirow{2}{*}{$\begin{array}{l}\text { Other chronic } \\
\text { diseases }\end{array}$} & No & 16 & $84.2 \%$ & 308 & $98.1 \%$ & \multirow{2}{*}{$<0.001$} \\
\hline & Yes & 3 & $15.8 \%$ & 6 & $1.9 \%$ & \\
\hline \multirow{2}{*}{ Co-morbidity } & No & 2 & $10.5 \%$ & 193 & $61.5 \%$ & \multirow{2}{*}{$<0.001$} \\
\hline & Yes & 17 & $89.5 \%$ & 121 & $38.5 \%$ & \\
\hline
\end{tabular}

Regarding the laboratory findings, there were significant difference ( $\mathrm{p}$-value $<0.001)$ were found between died and recovered patients regarding white blood cells, lymphocytes and neutrophilic lymphocytic ratio, as there was significant lower mean \pm SD $(10.5 \pm 7.5 \%)$ of lymphocyte count in died case than recovered cases mean \pm SD $(25.7 \pm 12.2$ $\%)$. The neutrophilic lymphocytic ratio was significant higher in died cases of COVID-19 ( $\mathrm{p}<0.001)$. White blood cells were significantly higher in died cases of COVID-19 mean \pm SD $(14.8 \pm 8.7 \times 103$ $\mathrm{mm}-3)$ than recovered cases of COVID$19(7.9 \pm 3.6 \times 103 \mathrm{~mm}-3) \quad(\mathrm{p}<0.001)$. There is significant difference ( $\mathrm{p}$-value < 0.05) were found between died and recovered patients of COVID-19 as regard neutrophil ( $p$ 0.004). But there is no significant difference ( $p$-value $>0.05$ ) were found between died and recovered patients of COVID-19 as regard hemoglobulin and platelets. In addition to that, there were significant higher mean \pm SD values of CRP $(\mathrm{mg} / \mathrm{dl})$, ferritin ( $\mathrm{ng} / \mathrm{ml})$, D. dimer $(\mathrm{ng} / \mathrm{ml})$ among died cases of COVID-19 $(66.8 \pm 43.5,892.2 \pm$ 484.2 and $252.2 \pm 75.8$ respectively) when compared with those recovered cases of COVID-19 (15.6 $\pm 23.5,247.2 \pm 251.5$ and $136.9 \pm 109.7$ respectively). As regard to mean $\pm \mathrm{SD}$ values of SGPT (IU/L), SGOT (IU/L), bilirubin $(\mathrm{mg} / \mathrm{dl})$, creatinine $(\mathrm{mg} / \mathrm{dl})$, blood urea $(\mathrm{mg} / \mathrm{dl})$, it is significant higher in died cases of COVID-19 when compared with those recovered cases of COVID-19 $(\mathrm{p}<0.001)$. The serum albumin levels $(\mathrm{mg} / \mathrm{dl})$ mean \pm SD were significant lower in died cases of COVID-19 $(3.2 \pm 0.4)$ than recovered 
cases of COVID-19 $(3.7 \pm 0.5)(\mathrm{p}<0.001) \quad$ (Table 3).

Table (3): Comparisons of laboratory tests between died and recovered cases among COVID-19 patients

\begin{tabular}{|c|c|c|c|c|}
\hline \multicolumn{2}{|l|}{ Parameters } & $\begin{array}{c}\text { Died } \\
(n=19)\end{array}$ & $\begin{array}{c}\text { Recovered } \\
(n=314)\end{array}$ & p-value \\
\hline \multirow{2}{*}{$\begin{array}{c}\text { WBCs } \\
\left(\mathrm{x}^{3} 0^{3} / \mathrm{ul}\right)\end{array}$} & $\begin{array}{l}\text { Mean } \\
\pm \text { SD }\end{array}$ & $14.8 \pm 8.7$ & $7.9 \pm 3.6$ & \multirow{2}{*}{$<0.001$} \\
\hline & Median & 11.1 & 7.9 & \\
\hline \multirow{2}{*}{$\begin{array}{l}\text { Neutrophil } \\
(\%)\end{array}$} & $\begin{array}{l}\text { Mean } \\
\pm \text { SD }\end{array}$ & $75.7 \pm 13.2$ & $66.5 \pm 13.5$ & \multirow[t]{2}{*}{0.004} \\
\hline & Median & 78.4 & 67.6 & \\
\hline \multirow{2}{*}{$\begin{array}{c}\text { Lymphocyte } \\
(\%)\end{array}$} & $\begin{array}{l}\text { Mean } \\
\pm \text { SD }\end{array}$ & $10.5 \pm 7.5$ & $25.7 \pm 12.2$ & \multirow[t]{2}{*}{$<0.001$} \\
\hline & Median & 8.7 & 25 & \\
\hline \multirow{2}{*}{$\begin{array}{c}\text { Neutrophilic/ } \\
\text { Lymphocyte } \\
\text { ratio }\end{array}$} & $\begin{array}{l}\text { Mean } \\
\pm \text { SD }\end{array}$ & $14.4 \pm 15.6$ & $4.9 \pm 8.5$ & \multirow{2}{*}{$<0.001$} \\
\hline & Median & 8.1 & 2.8 & \\
\hline \multirow{2}{*}{$\underset{(\mathrm{g} / \mathrm{dl})}{\text { Hemoglobulin }}$} & $\begin{array}{c}\text { Mean } \\
\pm \text { SD } \\
\end{array}$ & $12.4 \pm 2.5$ & $12.5 \pm 1.5$ & \multirow[t]{2}{*}{0.827} \\
\hline & Median & 12.7 & 12.5 & \\
\hline \multirow{2}{*}{$\begin{array}{l}\text { Platelets } \\
(\mathbf{x 1 0} / \mathbf{u l})\end{array}$} & $\begin{array}{l}\text { Mean } \\
\pm \text { SD }\end{array}$ & $265.5 \pm 139.7$ & $244.9 \pm 92.9$ & \multirow[t]{2}{*}{0.790} \\
\hline & Median & 234 & 238 & \\
\hline \multirow[t]{2}{*}{ CRP (mg/L) } & $\begin{array}{l}\text { Mean } \\
\pm \text { SD }\end{array}$ & $66.8 \pm 43.5$ & $15.6 \pm 23.5$ & \multirow[t]{2}{*}{$<0.001$} \\
\hline & Median & 65 & 5 & \\
\hline \multirow{2}{*}{$\begin{array}{c}\text { Ferritin } \\
(\mathbf{n g} / \mathbf{m l})\end{array}$} & $\begin{array}{l}\text { Mean } \\
\pm \text { SD }\end{array}$ & $892.2 \pm 484.2$ & $\begin{array}{l}247.2 \pm \\
251.5 \\
\end{array}$ & \multirow[t]{2}{*}{$<0.001$} \\
\hline & Median & 760 & 156 & \\
\hline \multirow{2}{*}{$\begin{array}{c}\text { D-Dimer } \\
\text { (ng/ml) }\end{array}$} & $\begin{array}{l}\text { Mean } \\
\pm \text { SD }\end{array}$ & $252.2 \pm 75.8$ & $\begin{array}{c}136.9 \pm \\
109.7 \\
\end{array}$ & \multirow[t]{2}{*}{$<0.001$} \\
\hline & Median & 236 & 109 & \\
\hline \multirow[t]{2}{*}{ SGOT (U/L) } & $\begin{array}{c}\text { Mean } \\
\pm \text { SD }\end{array}$ & $53.1 \pm 19.5$ & $33.7 \pm 20.3$ & \multirow[t]{2}{*}{$<0.001$} \\
\hline & Median & 46 & 30 & \\
\hline \multirow[t]{2}{*}{ SGPT (U/L) } & $\begin{array}{l}\text { Mean } \\
\pm \text { SD }\end{array}$ & $47.3 \pm 21.6$ & $37.7 \pm 26.6$ & \multirow[t]{2}{*}{0.013} \\
\hline & Median & 44 & 32 & \\
\hline \multirow{2}{*}{$\begin{array}{c}\text { Bilirubin } \\
\text { (mg/dl) }\end{array}$} & $\begin{array}{l}\text { Mean } \\
\pm \text { SD }\end{array}$ & $1.3 \pm 0.5$ & $0.96 \pm 0.2$ & \multirow[t]{2}{*}{$<0.001$} \\
\hline & Median & 1.2 & 1 & \\
\hline \multirow{2}{*}{$\begin{array}{c}\text { Serum } \\
\text { albumin }(g / d l)\end{array}$} & $\begin{array}{l}\text { Mean } \\
\pm \text { SD }\end{array}$ & $3.2 \pm 0.4$ & $3.7 \pm 0.5$ & \multirow[t]{2}{*}{$<0.001$} \\
\hline & Median & 3.1 & 3.7 & \\
\hline \multirow{2}{*}{$\begin{array}{l}\text { Creatinine } \\
\text { (mg/dl) }\end{array}$} & $\begin{array}{c}\text { Mean } \\
\pm \text { SD }\end{array}$ & $3.04 \pm 3.2$ & $0.83 \pm 0.3$ & \multirow[t]{2}{*}{$<0.001$} \\
\hline & Median & 1.6 & 0.8 & \\
\hline \multirow[t]{2}{*}{ Urea (mg/dl) } & $\begin{array}{c}\text { Mean } \\
\pm \text { SD }\end{array}$ & $125.7 \pm 104.5$ & $41.9 \pm 19.5$ & \multirow[t]{2}{*}{$<0.001$} \\
\hline & Median & 90 & 36.9 & \\
\hline
\end{tabular}


Mean \pm SD of HbA1c value was significant higher in died diabetic cases $(10.5 \pm 0.5 \%)$ when compared with those recovered diabetic cases $(9.2 \pm 1.2 \%)(\mathrm{p}<$ $0.001)$. Normal $x$-ray was recorded in 4 died cases of COVID-19 (21.1\%) and the remaining cases showed bilateral lung opacities in varies degree of mild, moderate and sever (4, 9 and 2 cases respectively). While x-ray in recovered cases of COVID-19, 156 (49.7\%) cases were reported normally. There were findings in CT chest of all including cases.
Ground glass opacities were recorded in $100 \%$ of recovered COVID-19 patients, however, $94.7 \%$ (18 cases) in died cases of COVID-19 patients exhibited crazy paving appearance. Regarding duration of treatment (days), there no significant difference were found between died cases of COVID-19 mean \pm SD $(10.4 \pm 6.2)$ and recovered patients of COVID-19 mean \pm SD $(13.6 \pm 7.8)(\mathrm{p}$-value $>0.05)$ (Table 4). 
Table (4): Comparisons between died and recovered cases among COVID-19 patients according to HbA1c in diabetic patients, chest X-ray \& CT, chest CT finding and duration of treatment

\begin{tabular}{|c|c|c|c|c|c|c|c|c|}
\hline \multicolumn{2}{|c|}{ Parameters } & \multicolumn{3}{|c|}{ Outcomes } & & \multicolumn{2}{|c|}{$\begin{array}{c}\text { Recovered } \\
(\mathbf{n}=57)\end{array}$} & p-value \\
\hline \multirow{3}{*}{\multicolumn{2}{|c|}{ HbA1C (\%) }} & \multirow{2}{*}{\multicolumn{2}{|c|}{$\begin{array}{r}\text { Mean } \pm S \\
\text { Median }\end{array}$}} & & & 9.2 & & \multirow{3}{*}{$<0.001$} \\
\hline & & & & & 10.7 & \multicolumn{2}{|c|}{9.3} & \\
\hline & & \multicolumn{3}{|c|}{ Controlled } & $0 \%$ & 3 & $5.3 \%$ & \\
\hline \multicolumn{3}{|c|}{$\begin{array}{ll}\text { Outcomes } & \text { Oumeters } \\
\end{array}$} & \multicolumn{2}{|c|}{$\begin{array}{c}\text { Died } \\
(n=19)\end{array}$} & \multicolumn{2}{|c|}{$\begin{array}{c}\text { Recovered } \\
(n=314)\end{array}$} & \multicolumn{2}{|r|}{ p-value } \\
\hline \multirow{4}{*}{$\begin{array}{l}\vec{x} \\
\vec{x} \\
\overrightarrow{0} \\
\overrightarrow{0}\end{array}$} & \multicolumn{2}{|c|}{ Normal } & 4 & $21.1 \%$ & 156 & $49.7 \%$ & \multirow{4}{*}{\multicolumn{2}{|c|}{$<0.001$}} \\
\hline & \multicolumn{2}{|c|}{$\begin{array}{c}\text { Bilateral mild lung } \\
\text { opacity }\end{array}$} & 4 & $21.1 \%$ & 142 & $45.2 \%$ & & \\
\hline & \multicolumn{2}{|c|}{$\begin{array}{l}\text { Bilateral moderate } \\
\text { lung opacity }\end{array}$} & 9 & $47.4 \%$ & 8 & $2.5 \%$ & & \\
\hline & \multicolumn{2}{|c|}{$\begin{array}{c}\text { Bilateral severe lung } \\
\text { opacity }\end{array}$} & 2 & $10.5 \%$ & 8 & $2.5 \%$ & & \\
\hline \multirow{5}{*}{$\begin{array}{l}\bar{v} \\
\bar{v} \\
\bar{v}\end{array}$} & Scor & & 0 & $0 \%$ & 131 & $41.7 \%$ & \multirow{5}{*}{\multicolumn{2}{|c|}{$<0.001$}} \\
\hline & Scor & & 0 & $0 \%$ & 84 & $26.8 \%$ & & \\
\hline & Scor & & 1 & $5.3 \%$ & 55 & $17.5 \%$ & & \\
\hline & Scor & & 9 & $47.4 \%$ & 21 & $6.7 \%$ & & \\
\hline & Scor & & 9 & $47.4 \%$ & 23 & $7.3 \%$ & & \\
\hline
\end{tabular}

\begin{tabular}{|c|c|c|c|c|c|c|}
\hline \multicolumn{2}{|c|}{ Outcomes } & \multicolumn{2}{|c|}{$\begin{array}{c}\text { Died } \\
(\mathbf{n = 1 9})\end{array}$} & \multicolumn{2}{c|}{$\begin{array}{c}\text { Recovered } \\
(\mathbf{n = 3 1 4})\end{array}$} & \multirow{2}{*}{ p-value } \\
\hline \multirow{2}{*}{ Parameters } & Bilateral GGO & 1 & $5.3 \%$ & 314 & $100 \%$ & \multirow{2}{*}{$<0.001$} \\
\cline { 2 - 6 } & $\begin{array}{c}\text { Crazy paving } \\
\text { appearance }\end{array}$ & 18 & $94.7 \%$ & 0 & $0 \%$ & $<$ \\
\hline
\end{tabular}

\begin{tabular}{|c|c|c|c|c|}
\hline \multicolumn{2}{|c|}{ Outcomes } & $\begin{array}{c}\text { Died } \\
(\mathbf{n = 1 9})\end{array}$ & $\begin{array}{c}\text { Recovered } \\
(\mathbf{n}=\mathbf{3 1 4})\end{array}$ & \multirow{2}{*}{ p-value } \\
\cline { 1 - 4 } $\begin{array}{c}\text { Parameters } \\
\text { Duration } \\
\text { (days) }\end{array}$ & Mean \pm SD & $10.4 \pm 6.2$ & $13.6 \pm 7.8$ & \multirow{2}{*}{$\mathbf{0 . 1 4 7}$} \\
\cline { 2 - 4 } & Median & 10 & 11 & \\
\hline
\end{tabular}


The overall mortality rate was $5.7 \%$ (19 cases) (Figure 2$)$.

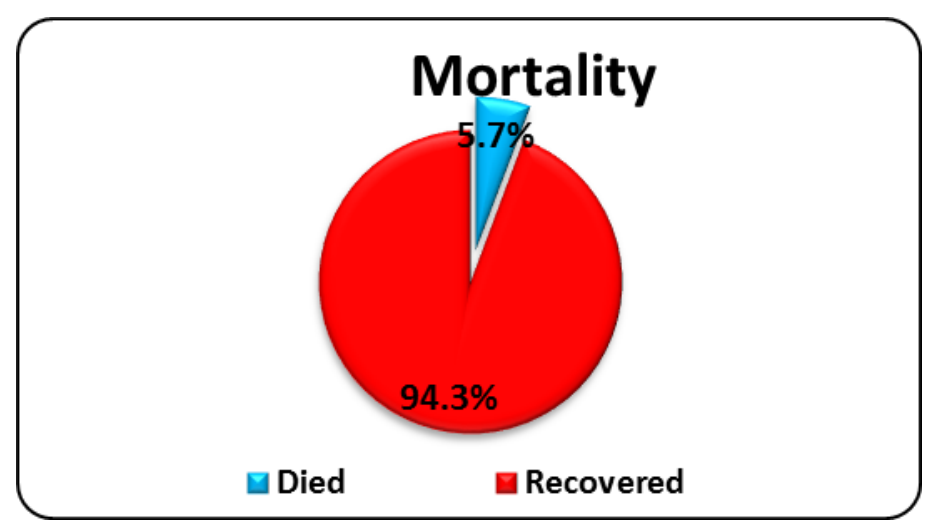

Figure (2): Description of mortality in all studied patients

\section{DISCUSSION}

In the current study, we found that cough, fever, dyspnea and sore throat are the main clinical presentations among COVID-19 patients, while diarrhea was the least clinical presentation. In agreement with our findings. Guan et al. (2020) reported that the most common COVID-19 presentations were fever and cough. Our findings raised the question of whether fever was an effective screening tool for COVID-19 patients as revealed that, almost half of patients did not have fever as an initial clinical presentation, and this was in agreement with Almazeedi et al. (2020). So, a febrile patient may be missed if the surveillance case definition focuses on fever detection. Our study was in stark contrast to another retrospective cohort study by Zhou et al. (2020) who reported about $94 \%$ above $37.3{ }^{\circ} \mathrm{C}$. This could be explained by small sample of their study (191 patients).

The diarrhea was a clinical presentation in $0.9 \%$ of our patients, and it was mild which seemed to be inconsistent with the pathogenicity of SARS-CoV-2. Chan et al. (2020) and Wang et al. (2020) were in agreement with our findings. A possible explanation is that SARS-CoV-2 in the sputum of COVID-19 patients transmitted to the digestive tract through swallowing. The virulence of SARS-CoV-2 in the digestive tract is weakened, and the virus is degraded into fragments that cause only mild digestive symptoms, but not serious gastrointestinal damage (Zhang et al., 2020). Another explanation is patients might be not oriented about diarrhea could be a symptom of COVID-19 infection.

The rapid outbreak of COVID-19 has been a matter of international concern as the disease is spreading rapidly. There is an urgent need to identify the risk populations with poor outcome. Our study identified that older age was one of the risk factors for disease severity and mortality. Ghweil et al. (2020) reported that severe COVID-19 was more frequent in older age. This finding reported by multiple studies from different geographic regions (Knights et al., 2020; Liu et al., 
2020; Mahase, 2020; Wang et al., 2020; Yang et al., 2020 and Zhou et al., 2020). This could be explained by age associated with decline cell mediated and humoral mediated immune function (Zhou et al., 2020). Also, ageing is associated with certain changes in pulmonary physiology, pathology and function during the period of lung infection. Therefore, age-related differences in responsiveness and tolerance become obvious, and lead to worse clinical outcomes in elderly individual (Liu et al., 2020).

Concerning tobacco smoking in the outcome of COVID-19 patients, our data showed a pooled prevalence of $28.5 \%$ current smoker, and smoking is not a risk of mortality in COVID-19. This was in agreement with Ghweil et al. (2020) who reported lack of significant difference regarding COVID-19 severity in terms of smoking. In contrast to our findings, a systematic review by Vardavas and Nikitara (2020) reported that smoking may be associated with a negative outcome. This heterogenicity could be due to difference in the study regions.

Regarding the contribution of increase body weight in the outcome of COVID19 , the obese patients demonstrate insulin resistance and over activity of the renin angiotensin-aldosterone system (RAAS) which is implicated with worse outcomes in COVID-19 infection. Furthermore, Angiotensin-converting enzyme 2 expressions in adipose tissue is higher than in lung tissue, which means that adipose tissue may be vulnerable to COVID-19 infection, so that, the obese population have more adipose tissue and consequently higher ACE2 levels (Gomar et al.., 2020). Hussain et al. (2020) reported in meta-analysis study, there is increase of mortality in obese patient infected with COVID-19. Our data confirmed the previous results. This could be attributed to impaired lung functions and increased levels of circulating proinflammatory cytokines, endothelial dysfunction and hypercoagulability associated with obesity.

The impact of co-morbidities is important on the outcomes for COVID-19 patients, helping clinicians to establish risk stratification of COVID-19 patients as early as possible. Diabetes mellitus, hypertension, chronic obstructive pulmonary disease and ischemic heart disease were the most prevalent chronic diseases in our cohort. These findings were similar to a meta-analysis study of Emami et al. (2020) who reported that hypertension, cardiovascular diseases, and diabetes mellitus were the most prevalent underlying diseases among hospitalized COVID-19 patients. Also, our study was in agreement with Ghweil et al., (2020). There is a higher risk for COVID-19 among diabetic patients because of the associated dysregulation of angiotensinconverting enzyme 2 (Marhl et al., 2020). Also, our study revealed that the presence of diabetes mellitus could be a significant predictor for mortality of COVID-19 patients. In line with our findings (Guan et al., 2020; Guo et al., 2020; Wang et al., 2020 and Zhou et al., 2020), and this could be explained by increased angiotensin-converting enzyme 2 expression, impaired $\mathrm{T}$ cell function and increase interlukin-6 (Singh et al., 2020). Glycemic control is important in any patient who has COVID-19. Our study revealed that poor glycemic control had increased risk of death that confirming 
previous results of Zhu et al. (2020). In contrast to our study, Alkundi et al. (2020) found no difference in mortalities based on the diabetes status, control or complications. These variations may have been due to differences in research methods including sample size and population types.

It has been reported that COVID-19 infection could induce some changes in hematological indices (Fan et al., 2020). In our study, the lymphocytic count and neutrophilic lymphocyte ratio were lower in died cases of COVID-19. Monitoring of such hematologic parameters may help to identify patients who may have a risk for worse outcome. Ghweil et al. (2020) reported that lymphopenia is significantly associated with the severity of COVID-19. Our results were consistent with other international data reported by Fan et al. (2020), Li and Fan (2020) and Knights et al. (2020). Regarding to white blood cell count and neutrophils, both were within normal ranges in our cohort despite it was higher in died patients. This was in contrast to Ghweil et al. (2020) who reported significantly lower mean value of white blood cells which could be due to small sample size of their study.

In the present study, our findings revealed that higher $\mathrm{CRP}$ and ferritin among died cases when compared with those who have recovered. It was due to infection with COVID-19 induces acute phase reactant production. These findings were in concordance with Ghweil et al. (2020), Li and Fan (2020), Liu et al. (2020) and Rodriguez et al. (2020).

Concerning D. dimer and in the outcome among COVID-19 patients, it is worth noting that our findings suggested associations between D-dimer levels and disease severity and mortality. This was explained by hyperfibrinolysis state and increased inflammatory burden induced in SARS-COV-2 infection. Several reports showed the same findings (Yao et al., 2020 and Zhou et al., 2020). Also, a result of a systematic review and meta-analysis by Paliogiannis et al. (2020) reported that serum D-dimer concentrations in patients with severe COVID-19 are significantly higher. Our data showed that D-dimer levels were significantly correlated with inflammatory markers (CRP, ferritin) in severe cases, highlighting that inflammation considered as a cause of coagulation activation among COVID -19 patients. In contrast to our result, $W u$ et al. (2020) found that D. dimer elevated only in 3 out of 80 patients which could be attributed to that their cases are mild COVID-19 infection, and small number of patients.

Our analysis showed that raised SGPT and SGOT serum levels and low serum albumin levels were associated with severity and mortality among COVID-19 patients. Our findings confirming the previous results by Alqahtan et al. (2020), Aly et al. (2020), Chen et al. (2020) and Ghweil et al. (2020). We also found that patients with abnormal liver function had higher inflammatory marker, which may be related to the immune response after virus infection.

We demonstrated that in patients diagnosed with COVID-19, kidney function elevation upon admission was common in died cases. It seems that lowoxygen delivery to kidney in the setting of this disease may lead to ischemic damage of the kidney. Our result was in agreement 
with Qian et al. (2020). In contrast to our result, Ghweil et al. (2020) reported no significant differences between COVID19 severity as regards the frequency percentage of creatinine levels, Also, Wang et al. (2020) reported that COVID 19 infection does not result in acute kidney injury. This difference could be explained by the small number of patients in their study.

The median length of hospital stay was about 10-11 days. This was similar to the median length of stay observed in Guan et al. (2020), i.e. 12 days. The length of the stay was longer in Almazeedi et al. (2020), i.e. 18 days. This may be due to difference in discharge criteria.

In terms of radiological images, we determined that $48.04 \%$ of patients had a normal X-ray as reported by a radiologist. This was in agreement with Wong et al. (2020) who reported that $31 \%$ of COVID19 had normal initial chest X-ray. In contrast to our study, Almazeedi et al. (2020) reported that $76.3 \%$ had normal Xray. These variations may have been due to most of included subjects in their study were asymptomatic or have mild symptoms. In our study, there were radiological findings in $\mathrm{CT}$ chest of all patients. These findings raise the concern whether $\mathrm{X}$ - ray chest is enough as diagnostic image in COVID-19 patients. Regarding to CT chest, our results showed that the findings were bilateral peripheral ground glass opacity among patients who recovered from COVID- 19 infection, while in non-survivor cases their CT chest revealed a crazy-paving appearance. So, $\mathrm{CT}$ chest findings were a predictor in the severity and mortality of COVID-19 infection. The same findings were reported by multiple studies (Ghweil et al., 2020; Majidi \& Niksolate 2020; Song et al., 2020 and Wang et al., 2020).

The overall mortality rate is different between studies, as it depends on many factors like age, severity of COVID-19 infection and associated comorbidities of included individuals. In our cohort, mortality rate was higher than Almazeedi et al. (2020) and Guan et al. (2020) who reported $1.7 \%$ and $1.4 \%$ respectively. This may reflect that, included patients in these studies were asymptomatic or have had milder symptoms. But our mortality rate was much lower than the other large retrospective cohort studies, i.e. Wu et al. (2020) showed $21.9 \%$ mortality and Zhou et al. (2020) showed $28.3 \%$ mortality. This heterogeneity is probably due to differences in the case inclusion criteria. However, our results were closer to the mortality rate indicated by official national statistics.

\section{CONCLUSION}

Measuring temperature is not an effective screening tool for COVID-19. Age, Obesity, co-morbidities, lymphopenia, increase inflammatory marker and elevated D. dimer could be used as a predictor of outcome in COVID19 patients.

Our study suffered from the usual limitations of the small sample. The relatively small number of mortality patients in this study limited the statistical power of the analysis.

\section{REFERENCES}

1. Adekunle S, Chuku O, Aleksandra M, Risha P, Kokab Y, Priyank D, Zaheeda $H$, Inderbir $P$, Jasmine $M$ and Mohsin A (2020): Comorbidity and its Impact on 
Patients with COVID-19. SN Compr Clin Med., 25: 1-8.

2. Alkundi A, Mahmoud I, Musa A, Naveed $S$ and Alshawwaf $M$ (2020): Clinical characteristics and outcomes of COVID-19 hospitalized patients with diabetes in the United Kingdom: A retrospective single centre study. Diabetic Research and Clinical Practice, 165: 108263.

3. Almazeedi S, Al-Youha S, Jamal M rt, Al-Haddad M, Al-Muhainia A and AlSabaha S (2020): Characteristics, risk factors and outcomes among the first consecutive 1096 patients diagnosed with COVID-19 in Kuwait. Clinical Medicine., 24: 100448.

4. Alqahtani JS, Oyelade T, Aldhahir AM, Alghamdi S, Almehmadi M, Alqahtani A, Quaderi S, Mandal S and Hurst J (2020): Prevalence, severity and mortality associated with COPD and Smoking in patients with COVID-19: A rapid systematic review and metaanalysis. PLoS One, 15(5):e0233147.

5. Aly MH, Rahman SS, Ahmed WA, Alghamedi MH, Al Shehri AA, Alkalkami AM and Hassan MH (2020): Indicators of critical illness and predictors of mortality in COVID-19 patients. Infect Drug Resist., 13:1995-2000.

6. Chan JF, Yuan S, Kok KH, Wang KK, Chu H, Yang J, Xing F, BNurs JL, Yan CC, Shan RW, Tsoi HW, Fai SK, Chan KH, Man VK, Chan WM, Daniel J, Cai JP, Chung VC and Yuen KY (2020): A familial cluster of pneumonia associated with the 2019 novel coronavirus indicating person-to- person transmission: a study of a family cluster. Lancet, 395 (10223):514-523.

7. Chen N, Zhou M, Dong X, Qu J, Gong F, Han Y, Qiu Y, Wang J, Liu Y, Wei $Y$, Xia J, Yu T, Zhang $X$ and Zhang $L$ (2020): Epidemiological and clinical characteristics of 99 cases of 2019 novel coronavirus pneumonia in Wuhan, China: a descriptive study. Lancet, 395(10223): 507-51.

8. Emami A, Javanmardi F, Pirbonyeh $\mathbf{N}$ and Akbari A (2020): Prevalence of underlying diseases in hospitalized patients with COVID-19: a systematic review and meta-analysis. Arch Acad Emerg Med., 8(1):e35.

9. Fan BE, Chong VCL, Chan SSW, Chan SSW, Lim GH, Lim KGE, Tan GB, Mucheli SS, Kuperan P and Ong KH (2020): Hematologic parameters in patients with COVID-19 infection. Am J Hematol., 95(6):E131- E134.

10. Ghweil AA, Hassan MH, Khodeary A, Mohamed AO, Mohamed HM, Abdelazez AA, Osman HA and Bazeed SES (2020): Characteristics, Outcomes and Indicators of Severity for COVID-19 Among Sample of ESNA Quarantine Hospital's Patients, Egypt: A Retrospective Study. Infection and Drug Resistance, 13: 2375-2383.

11. Gomar SF, Lavie CJ, Mehra MR, Henry BM and Lippi G (2020): Obesity and Outcomes in COVID-19: When an Epidemic and Pandemic Collide. Mayo Clin Proc., 95(7): 1445-1453.

12. Guan GW, Gao L, Wang JW, Wen XJ, Mao TH, Peng SW, Zhang T, Chen XM and Lu FM (2020): Exploring the mechanism of liver enzyme abnormalities in patients with novel coronavirusinfected pneumonia. Zhonghua Gan Zang Bing Za Zhi., 28(2):100-106.

13. Guan $W$, Liang $W$, Zhao $Y$, Liang $H$, Chen ZZ, Li Y, Liu X, Chen R, Tang C, Wang T, Ou C, Li L, Chen P, Sang L, Wang W, Li J, Li C, Ou L, Cheng B, Xiong S, Ni Z, Xiang J, Hu Y, Liu L, Shan H, Lei C, Peng Y, Wei L, Liu Y, Hu Y, Peng P, Wang J, Liu J, Chen Z, Li G, Zheng Z, Qiu S, Luo J, Ye C, Zhu 
S, Cheng L, Ye F, Li S, Zheng J, Zhang $\mathrm{N}$, Zhong $\mathrm{N}$ and He $\mathrm{J}$ (2020): Comorbidity and its impact on 1590 patients with Covid-19 in China: A Nationwide Analysis. European Respiratory Journal., 55 (5): 2000547.

14. Guan W-J, Ni Z-Y, Hu Y, Liang W-H, Ou C-Q, He J-X, Liu L, Shan H, Lei CL, Hui DS, Du B and Li L-J (2020): Clinical characteristics of coronavirus disease 2019 in China. N Engl J Med., 382:1708-1720.

15. Guo W, Li M, Dong Y, Zhou H, Zhang Z, Tian C, Qin R, Wang H, Shen Y, Du K, Zhao L, Fan H, Luo $S$ and Hu D (2020): Diabetes is a risk factor for the progression and prognosis of COVID-19. Diabetes Metabolism Research and Reviews., 36(7): 3319.

16. Huang, C., Wang, Y., Li, X., Ren, L., Zhao, J., Hu, $Y$ and Cheng, $Z$ (2020): Clinical features of patients infected with 2019 novel coronavirus in Wuhan, China. The Lancet, 395: 497-506.

17. Hussain A, Mahawar K, Xia Z, Yang W and EL-Hasani $S$ (2020): Obesity and mortality of COVID-19. Meta-analysis. Obes Res Clin Pract., 14(4): 295-300.

18. Knights $H$, Mayor $N$ and Millar $K$ (2020): Characteristics and outcomes of patients with COVID-19 at a district general hospital in Surrey, UK. Clinical Medicine., (20), 5: 148-53.

19. Li J and Fan JG (2020): Characteristics and mechanism of liver injury in 2019 coronavirus disease. $\mathrm{J}$ Clin Transl Hepatol., 8(1):13-17.

20. Lippi G, Mattiuzzi C, Sanchis-Gomar F and Henry BM (2020): Clinical and demographic characteristics of patients dying from COVID-19 in Italy versus China. Journal of Medical Virology, 92(10):1699-2249.
21. Liu K, Chen $Y$, Lin $R$ and Han $K$ (2020): Clinical features of COVID-19 in elderly patients: A comparison with young and middle-aged patients. Journal of Infection., 80(6): 14-18.

22. Liu Y, Mao B, Liang S, Yang J, Lu H, Chai Y, Wang L, Zhang L, Li Q, Zhao L, He Y, Gu X, Ji X, Li L, Jie Z, Li Q, Li X, Lu H, Zhang W, Song Y, Qu J and $\mathrm{Xu} \mathrm{J} \mathrm{(2020):} \mathrm{Association} \mathrm{between}$ age and clinical characteristics and outcomes of COVID-19. Eur Respir J, 55(5): 2001112.

23. Lu, R., Zhao, X., Li, J., Niu, P., Yang, B., Wu, $\mathrm{H}$ and Bi, Y (2020): Genomic characterization and epidemiology of 2019 novel coronavirus: implications for virus origins and receptor binding. The Lancet, 395: 565-574.

24. Mahase $\mathbf{E}$ (2020): Covid-19: death rate is $0.66 \%$ and increases with age, study estimates. British Medical Journal, 369: 1327.

25. Majidi $H$ and Niksolat $F$ (2020): Chest CT in patients suspected of COVID-19 infection: A reliable alternative for RTPCR. American Journal of Emergency Medicine, 158887: 3.

26. Marhl M, Grubelnik V, Magdič $M$ and Markovič $R$ (2020): Diabetes and metabolic syndrome as risk factors for COVID-19. Diabetes Metabolic Syndrome, 14(4):671-677.

27. Paliogiannis $\mathbf{P}$, Mangoni A, Dettori $\mathbf{P}$, Nasrallah G, Pintus G and Zinellu A (2020): D-Dimer Concentrations and COVID-19 Severity: A Systematic Review and Meta-Analysis. Front. Public Health, 3389: 432.

28. Pan Y, Zhang D, Yang P, Poon LLM and Wang $Q$ (2020): Viral load of SARS-CoV-2 in clinical samples. Lancet Infect Dis., 20(4): 411-2. 
29. Qian JY, Wang B and Liu BC (2020): Acute kidney injury in the 2019 Novel Coronavirus disease. Kidney Dis., 6:318323.

30. Richardson S, Hirsch JS, Narasimhan M, Crawford JM, McGinn $T$ and Davidson KW (2020): Presenting characteristics, comor- bidities, and outcomes among 5700 patients hospitalized with COVID-19 in the New York City area. 323(20):2052-2059.

31. Rodriguez-Morales AJC-O JA, Gutiérrez-Ocampo E, Villamizar- Peña R, Holguin-Rivera Y, EscaleraAntezana JP, Alvarado-Arnez LE, Bonilla-Aldana K, Franco-Paredes C, Henao-Martinez AF, Paniz-Mondolfi A, Lagos-Grisales GJ, Ramírez-Vallejo E, Suárez JA, Zambrano LI, VillamilGómez WE, Balbin-Ramon GJ, Rabaan AA and Sah R (2020): Clinical, laboratory and imaging features of COVID-19: A systematic review and meta-analysis, 34: 101623.

32. Singh AK, Gupta R, Ghosh $A$ and Misra A (2020): Diabetes in COVID-19: prevalence, pathophysiology, prognosis and practical considerations. Diabetes Metab Syndr., 14(4):303-310.

33. Song F, Shi N, Shan F, Zhang Z, Shen J, Lu H, Ling Y, Jiang $Y$ and Shi $Y$ (2020): Emerging coronavirus 2019nCoV pneumonia. Radiology, 295: 1.

34. Vardavas CI and Nikitara $K$ (2020): COVID-19 and smoking: A systematic review of the evidence. Tob Induc Dis., 18: 20.

35. Wang D, Hu B, Hu C, Zhu F, Liu X, Zhang J, Wang B, Xiang $H$, Cheng $Z$, Xiong Y. Zhao $Y$, Li Y, Wang $X$ and Peng $Z$ (2020): Clinical Characteristics of 138 hospita- lized patients with 2019 novel coronavirus-infected pneumonia in Wuhan, China. JAMA, 323(11):10611069 .
36. Wang L, Li X, Chen H, Yan S, Li D, Li $Y$ and Gong $Z$ (2020): Coronavirus Disease 19 Infection Does Not Result in Acute Kidney Injury: An Analysis of 116 Hospitalized Patients from Wuhan, China. Am J Nephrol., 51:343-348.

37. Wang L, He W, Yu X, Hu D, Bao M, Liu H, Zhou J and Jiang $H$ (2020): Coronavirus disease 2019 in elderly patients: Characteristics and prognostic factors based on 4-week follow-up. J Infect., 80(6): 639-645.

38. Wang W, Tang $J$ and Wei $F$ (2020): Updated understanding of the outbreak of 2019 novel coronavirus (2019-nCoV) in Wuhan, China. J Med Virol., 92: 441447.

39. Wang YY, Jin YH, Ren XQ, Li YR, Zhang XC, Zeng $X T$ and Wang $X H$ (2020): Updating the diagnostic criteria of COVID-19 "suspected case" and "confirmed case" is necessary. Mil Med Res., 7(1): 17.

40. Wong HYF, Lam HYS, Fong AHT, Leung ST, Chin TWY, Lo CSY, Lui MMS, Lee JHY, Chiu KWH, Chung TWH, Lee EYP, Wan EYF, Hung IFN, Lam TPW, Kuo MD and Ng MY (2020): Frequency and distribution of chest radiographic findings in COVID-19 positive patients. Radiology, 296: 2 .

41. Wu J, Liu J, Zhao X, Liu C, Wang W, Wang, D, Xu W, Zhang C, Yu J, Jiang B, Cao $H$ and Li L (2020): Clinical Characteristics of Imported Cases of COVID-19 in Jiangsu Province: A Multicenter Descriptive Study. Clin Infect Dis., 71(15):706-712.

42. Xu Z, Shi L, Wang Y, Zhang J, Huang L, Zhang C, Liu S, Zhao P, Liu H, Zhu L, Tai Y, Bai C, Gao T, Song J, Xia P, Dong J, Zhao J and Wang FS (2020): Pathological findings of COVID-19 associated with acute respiratory distress 
syndrome. Lancet Respir Med., 8(4):420422.

43. Yang J, Zheng $Y$, Gou $X$, Pu K, Chen Z, Guo Q, Ji R, Wang H, Wang Y and Zhou Y (2020): Prevalence of comorbidities and its effects in patients infected with SARS-CoV-2: a systematic review and meta-analysis. Int $\mathbf{J}$ Infect Dis., 94:91-95.

44. Yao Y, Cao J, Wang Q, Shi Q, Liu K, Luo Z, Chen X, Chen S, Yu K, Huang $Z$ and Hu $B$ (2020): D-dimer as a biomarker for disease severity and mortality in COVID-19 patients: a case control study. Journal of Intensive Care, 8, Article number 49.

45. Zhang J, Wang X, Jia X, Li J, Hu K, Chen G, Wei J, Gong Z, Zhou C, Yu H, Yu M, Lei H, Cheng F, Zhang B, Xu Y, Wang $G$ and Dong W (2020): Risk factors for disease severity, unimprovement, and mortality in COVID19 patients in Wuhan, China. Clin Microbiol Infect., 26(6):767-772.
46. Zhou F, Yu T, Du R, Fan G, Liu Y, Liu $\mathrm{Z}$, Xiang $\mathrm{J}$, Wang $\mathrm{Y}$, Song $\mathrm{B}$, Gu $\mathrm{X}$, Guan L, Wei Y, Li H, Wu X, Xu J, Tu S, Zhang Y, Chen $H$ and Cao B (2020): Clinical course and risk factors for mortality of adult inpatients with COVID19 in Wuhan, China: a retrospective cohort study. Lancet, 395:1054-62.

47. Zhu L, She Z-G, Cheng $X$, Qin JJ, Zhang XJ, Cai J, Lei F, Wang H, Xie J, Wang W, Li H, Zhang P, Song X, Chen $X$, Xiang $M$, Zhang $C$, Bai $L$ and Xiang D (2020): Association of blood glucose control and outcomes in patients with COVID-19 and pre-existing type 2 diabetes. Cell Metab., 31(6): 1068-1077.

48. Zhu, N., Zhang, D., Wang, W., Li, X., Yang, B., Song, J and Niu, P (2020): A novel coronavirus from patients with pneumonia in China, 2019. New England Journal of Medicine. 382:727-733. 


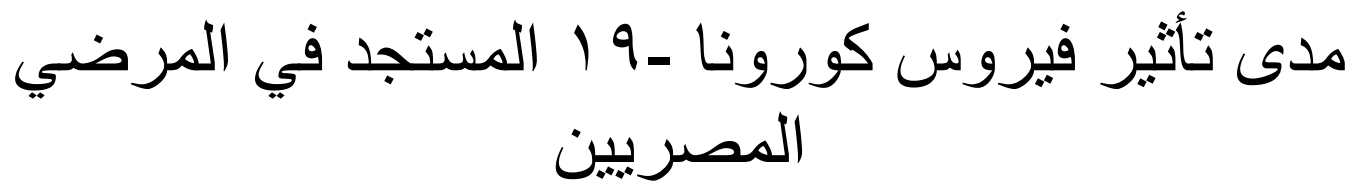

أحمد محمد خميس*، مجدى الدهان**، فتحى الغمرى*، محمد عجاج**، علاء هاشم ****، أحمد عليوه*

أقسام الباطنة العامة* والأثعة التشخيصية*** والكبد والجهاز الهضمى والأمر اض المعدية****، كلية الطب، جامعة الأزهر

E-mail: drahmedkhamiss2017@gmail.com

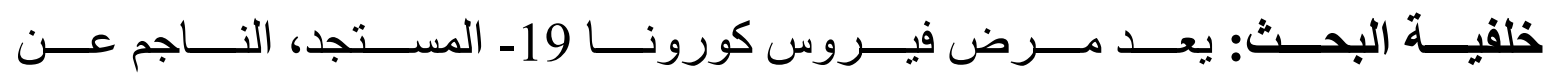

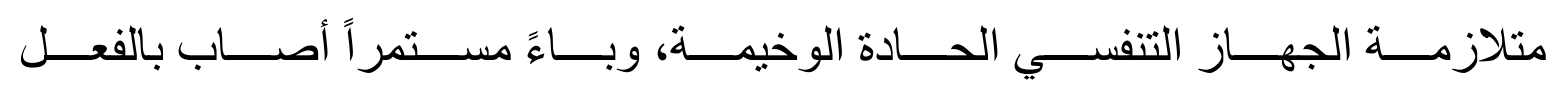

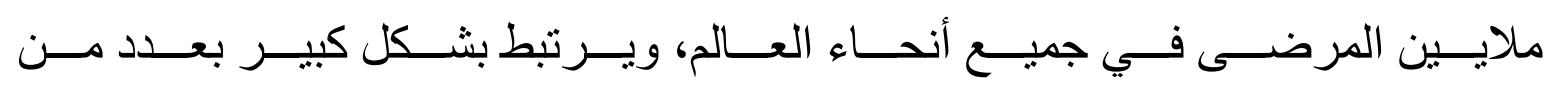

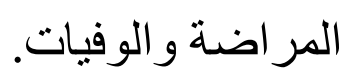

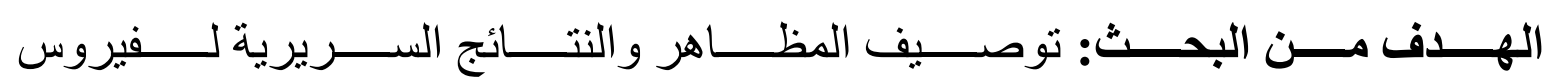
كورونا 19- المستجد في المرضى المصريين.

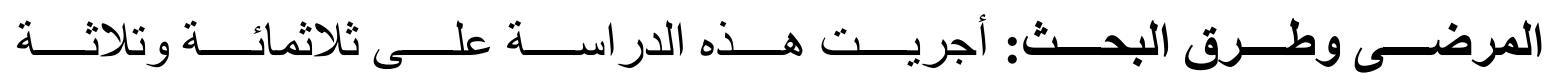

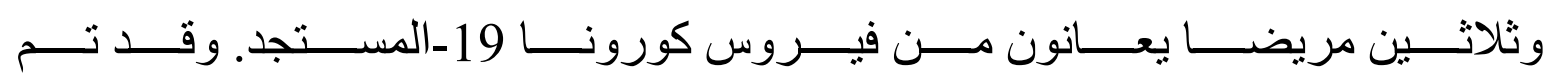

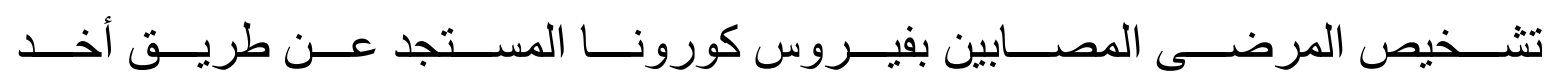
مســـة مـــن الحلــق و اللــوزتين لمعرفــة الحمــض النــووى الخــاص بـــالفيروس،

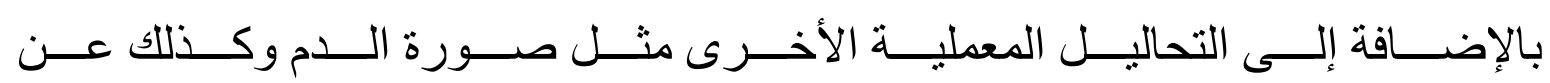
طريق الأشعة العادية و المقطعية.

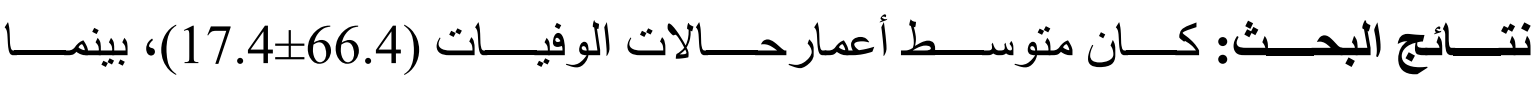

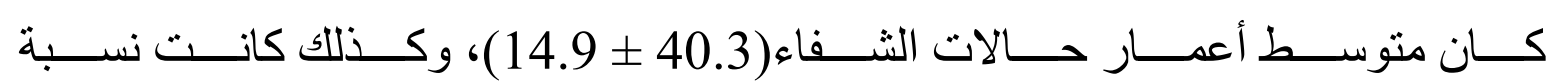

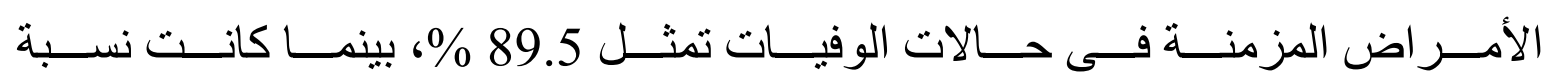

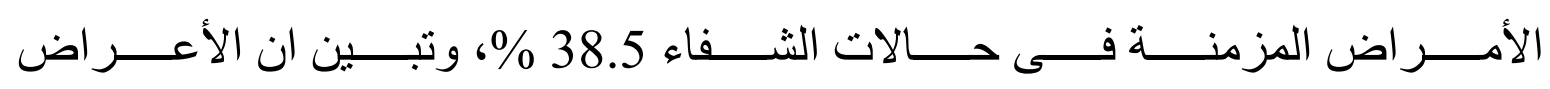




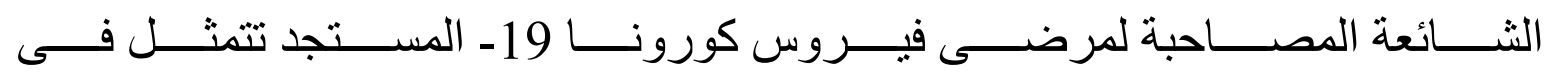

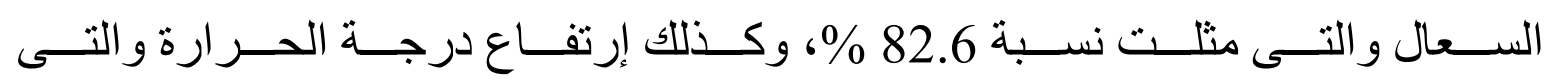
تمثل 51.7 \% بينما مثلت صعوبة التنفس 23.4\%.

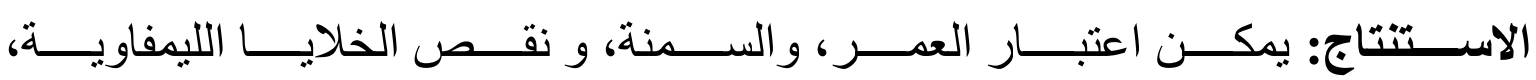

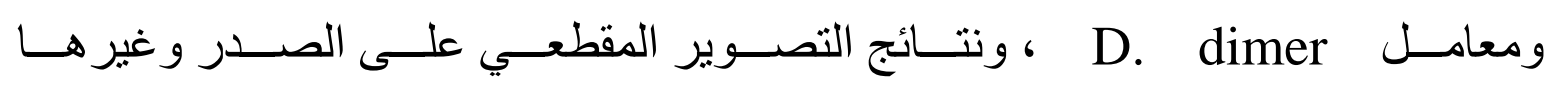

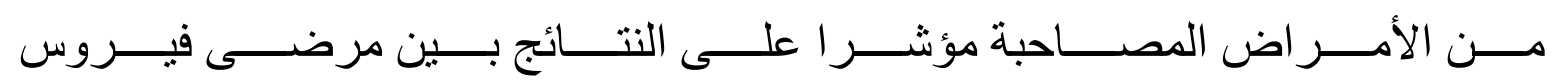

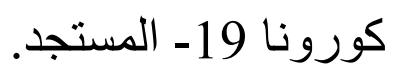

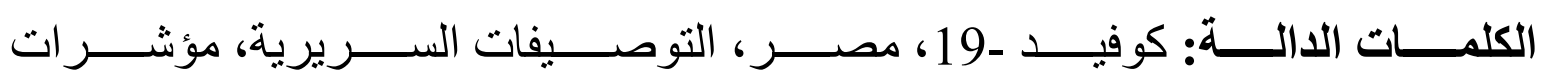

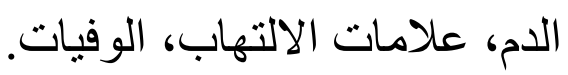

